\title{
Cerium nitrate and salicylic acid on vase life, lipid peroxidation, and antioxidant enzymes activity in cut lisianthus flowers
}

\author{
Firoozeh Pourzarnegar $^{1}\left(\mathbb{D}\right.$, Davood Hashemabadi $^{*}$ (D), Behzad Kaviani ${ }^{1}$ (D)
}

${ }^{1}$ Department of Horticultural Science, Rasht Branch, Islamic Azad University, Rasht, Iran

\begin{abstract}
Lisianthus is a major cut flower, but it has a short vase life. To prolong postharvest longevity and improve quantitative and qualitative traits of cut lisianthus flowers, an experiment was conducted on the basis of a Completely Randomized Design with eight treatments on 120 flower sprays in three replications. The experimental treatments included salicylic acid (SA) at the rates of 50, 100 and $200 \mathrm{mg} \mathrm{L}^{-1}$, cerium nitrate $\left[\mathrm{Ce}\left(\mathrm{NO}_{3}\right)_{3}\right]$ at the rates of $20,40,80$, and $200 \mu \mathrm{M}$, and control (distilled water). The results revealed that the flowers treated with $40 \mu \mathrm{M} \mathrm{Ce}\left(\mathrm{NO}_{3}\right)_{3}$ and those treated with $100 \mathrm{mg} \mathrm{L}^{-1}$ SA had the longest vase life of 15.42 and 15.20 days, respectively. Also, these treatments were most effective in improving water uptake, reducing microbial load at the stem end, and enhancing petals' protein content. The lowest malondialdehyde (18.65 $\mathrm{nmol} \mathrm{\textrm {g } ^ { - 1 }}$ fresh weight) was related to the treatment of $40 \mu \mathrm{M} \mathrm{Ce}\left(\mathrm{NO}_{3}\right)_{3}$ and $100 \mathrm{mg} \mathrm{L}^{-1} \mathrm{SA}$. These treatments showed the lowest polyphenol oxidase (PPO) activity, too. The activity of ascorbate peroxidase (APX) and peroxidase (POD) antioxidant enzymes was significantly higher in the flowers treated with $40 \mu \mathrm{M}$ $\mathrm{Ce}\left(\mathrm{NO}_{3}\right)_{3}$ and $100 \mathrm{mg} \mathrm{L}^{-1} \mathrm{SA}$. The treatment of $200 \mathrm{mg} \mathrm{L}^{-1} \mathrm{SA}$ had negative effects on all the recorded traits. So, it can be concluded that the treatment of cut lisianthus flowers with $40 \mu \mathrm{M} \mathrm{Ce}\left(\mathrm{NO}_{3}\right)_{3}$ and $100 \mathrm{mg} \mathrm{L}^{-1} \mathrm{SA}$ can prolong their postharvest longevity by reducing lipid peroxidation and increasing the activity of antioxidant enzymes.
\end{abstract}

Keywords: Eustoma grandiflorum 'Pink Picotee', ascorbate, peroxidase malondialdehyde, polyphenol oxidase, vase solution.

Resumo

Nitrato de cério e ácido salicílico na vida de vaso, peroxidação lipídica e atividade de enzimas antioxidantes em flores cortadas de lisianthus

Lisianthus é uma flor de corte importante, mas tem vida de vaso curta. Para prolongar a longevidade pós-colheita e melhorar as características quantitativas e qualitativas de flores cortadas de lisianthus, um experimento foi conduzido com base em um Projeto Completamente Randomizado com oito tratamentos em 120 pulverizações de flores em três repetições. Os tratamentos experimentais incluíram ácido salicílico (SA) nas taxas de 50, 100 e $200 \mathrm{mg} \mathrm{L}^{-1}$, nitrato de cério $\left[\mathrm{Ce}\left(\mathrm{NO}_{3}\right)_{3}\right]$ nas doses de $20,40,80$ e $200 \mu \mathrm{M}$ e controle (destilado água). Os resultados revelaram que as flores tratadas com $40 \mu \mathrm{M} \mathrm{Ce}\left(\mathrm{NO}_{3}\right)_{3}$ e aquelas tratadas com $100 \mathrm{mg}$ $\mathrm{L}^{-1} \mathrm{SA}$ tiveram a maior vida útil de vaso de 15,42 e 15,20 dias, respectivamente. Além disso, esses tratamentos foram mais eficazes em melhorar a absorção de água, reduzindo a carga microbiana na extremidade do caule e aumentando o conteúdo de proteína das

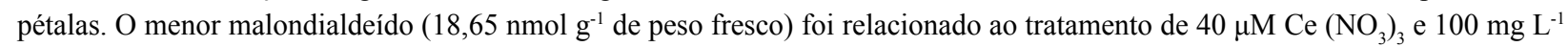
SA. Esses tratamentos também apresentaram a menor atividade da polifenol oxidase (PPO). A atividade das enzimas antioxidantes ascorbato peroxidase (APX) e pe-roxidase (POD) foi significativamente maior nas flores tratadas com $40 \mu \mathrm{M} \mathrm{Ce}\left(\mathrm{NO}_{3}\right)_{3}$ e $100 \mathrm{mg}$ $\mathrm{L}^{-1} \mathrm{SA}$. O tratamento com $200 \mathrm{mg} \mathrm{L}^{-1} \mathrm{SA}$ teve efeitos negativos em todas as características registradas. Assim, pode-se concluir que o tratamento de flores cortadas de lisianthus com $40 \mu \mathrm{M} \mathrm{Ce}\left(\mathrm{NO}_{3}\right)_{3}$ e $100 \mathrm{mg} \mathrm{L}^{-1}$ SA pode prolongar sua longevidade pós-colheita, reduzindo a peroxidação lipídica e aumentando a atividade de enzimas antioxidantes.

Palavras-chave: Eustoma grandiflorum 'Pink Picotee', ascorbato, malondialdeído peroxidase, polifenol oxidase, solução de vaso.

"Corresponding author: davoodhashemabadi@yahoo.com

https://doi.org/10.1590/2447-536X.v26i4.2227

Received July 27, 2020 | Accepted Sept 22, 2020 | Available online Oct 13, 2020

Licensed by CC BY 4.0 (https://creativecommons.org/licenses/by/4.0/)

Area Editor: Bruno Trevenzoli Favero 


\section{Introduction}

Lisianthus (Eustoma grandiflorum) is a major cut flower from the family Gentianaceae (Saeedi et al., 2015). Cut lisianthus flowers exhibit short vase life due to their susceptibility to ethylene (Ichimura et al., 1998) and xylem blockage (Sharifzadeh et al., 2014). In 2001, the production of lisianthus cut flowers in Japan, Europe and the United States was reported at 129, 122 and 14 million branches, respectively (Harbaugh, 2007). In 2016, in terms of production volume, lisiantos was ranked sixth among the ten best-selling flowers in the world with 69 million euros. The area under cultivation and the amount of lisianthus production in Iran in 1396 were 85.4 hectares and 152.6 million branches, respectively. Since postharvest longevity is a key attribute of cut flower supplies to target markets, researchers have always been looking for ways to extend postharvest longevity of these precious perishable products (Silva, 2008; Kader, 2003).

Salicylic acid (SA) is a plant growth regulator and a naturally occurring phenolic compound that is highly capable of controlling and reducing postharvest loss of different horticultural products. SA plays a significant role in the control of ethylene synthesis and activity, the reduction of respiration, and the build-up of resistance to diseases and oxidative stresses (Ding et al., 2002; Wollaston et al., 2003; Asghari and Aghdam, 2010). The positive effect of SA has been reported in prolonging postharvest longevity of gladiolus (Ezhilmathi et al., 2007), carnation (Kazemi et al., 2011) and lisianthus (Kazemi et al., 2011). Researchers argue that SA prolongs postharvest longevity of cut flowers by reducing ethylene synthesis (Bayat and Aminifard, 2017; Sirvastava and Dwivedi, 2000), inhibiting the growth and propagation of microorganisms and improving water uptake (Bayat and Aminifard, 2017; Mashhadian et al., 2012).

With the occurrence of stress in plants, the balance between the production and decomposition of oxygen active species is disturbed, under these conditions oxidative stress occurs. Increasing the production and activity of reactive oxygen species causes the destruction of macromolecules and accelerates aging in petals and other plant tissues. Plants resist the damaging effects of oxidative stress through various defense systems, including the enzymatic antioxidant defense system such as SOD, POD and CAT (Gerailoo and Ghasemnezhad, 2011; Kumar et al., 2008). SA as a compound extends the vase life of cut flowers is able to directly decompose reactive oxygen species; it also indirectly inhibits the activity of reactive oxygen species by regulating the activity of antioxidant enzymes and reduces the damaging effects of oxidative stress (Gerailoo and Ghasemnezhad, 2011). Mansouri (2012) reported that the treatment of chrysanthemums with SA contributed to maintaining membrane structure, hindering fresh weight loss, and increasing vase life. In the study of Alaey et al. (2012), the application of SA to the preservative solution of cut rose flowers resulted in the scavenging of reactive oxygen species (ROS) and the improvement of water uptake and prolonged the longevity of the cut flower versus the control. As well, SA application to the vase solution of rose 'Yellow Island' cut flowers retarded aging process by strengthening the antioxidant system and inhibiting the oxidative stress (Gerailoo and Ghasemnezhad, 2011). Kazemi et al. (2012) found that the application of $1.5 \mathrm{mM}$ $\mathrm{SA}+3 \%$ sucrose in the vase solution of cut carnation flowers reduced bacterial activity, ACC-oxidase activity, and malondialdehyde content significantly. It also preserved the cut flowers for a longer time after harvesting by enhancing membrane stability. The vase life in this treatment was 11 days and in control was 7.1 days. Therefore, this treatment increased the vase life compared to the control by 3.9 days.

Cerium $(\mathrm{Ce})$ is a key trace element on the Earth that influences plant growth and development positively (Yin et al., 2009; He and Loh, 2000). This element has antibiotic (Huang, 2002) and antioxidant properties (Yin et al., 2009; He and Loh, 2000). Cerium compounds are also known in particular for their uses in topical burn treatments due to their bacteriostatic and bactericidal effects. Later, studies confirmed the antiseptic effects of cerium(III) chloride, $\mathrm{Ce}(\mathrm{III})$ nitrate, and Ce(IV) sulfate and demonstrated particular susceptibility of both gram-negative and grampositive bacteria (which tend to coat burn wounds) to their effects. Cerium(III) nitrate in particular is a widely used treatment for burn wounds, exhibiting nearly a $50 \%$ reduction in death rate for patients with life-threatening burns when compared to patients who were administered silver nitrate treatments (Jessica and Yuji, 2015). There are reports on the role of this compound in alleviating the destructive effects of oxidative stresses (Wu et al., 2014; Liang et al., 2006) and improving the activity of ASA-GSH cycle, which is essential for reducing lipoperoxidation (Liu et al., 2016; Houa et al., 2018).

In postharvest physiology, cerium nitrate $\left[\mathrm{Ce}\left(\mathrm{NO}_{3}\right)_{3}\right]$ is used to prolong the longevity of cut flowers. The application of $\mathrm{Ce}\left(\mathrm{NO}_{3}\right)_{3}$ to the vase solution of rose cut flowers (Wang et al., 2017) and Lilium longiflorum cut flowers (Houa et al., 2018) enhances their longevity by increasing antioxidant activity and strengthening ASA-GSH cycle. According to Zheng and Guo (2018), the treatment of carnation cut flowers with $\mathrm{Ce}\left(\mathrm{NO}_{3}\right)_{3}$ reduced the accumulation of MDA and strengthened the metabolism of ascorbate and glutathione in petals. It also preserved the longevity of the cut flowers for a longer time by helping to maintain membrane stability. The present study aimed to shed light on the effect of pulse treatment of salicylic acid and cerium nitrate $\left[\mathrm{Ce}\left(\mathrm{NO}_{3}\right)_{3}\right]$ on the vase life and the related traits of cut lisianthus 'Pink Picotee' flowers.

\section{Materials and Methods}

\section{Plant materials and treatments}

To explore the effect of salicylic acid (SA) and cerium nitrate $\left[\mathrm{Ce}\left(\mathrm{NO}_{3}\right)_{3}\right]$ on the vase life and related traits of cut lisianthus 'Pink Picotee' flowers, an experiment was carried out based on a completely randomized design. The experimental treatments were composed of $\mathrm{Ce}\left(\mathrm{NO}_{3}\right)_{3}$ at four rates of $20,40,80$, and $200 \mu \mathrm{M}, \mathrm{SA}$ at three rates of 50,100 and $200 \mathrm{mg} \mathrm{L}^{-1}$, and control (distilled water) 
plus 3\% sucrose. The experiment was carried out at three replicates. Intact and uniformed flowers with the same size that were harvested at their bud stage were used for the trials. After their transfer to the laboratory, the flowers were recut at a height of $45 \mathrm{~cm}$ under water and were treated with the solutions for 24 hours. After the pulse treatment, the flowers were placed in a vase solution containing distilled water and were kept in a room at a temperature of $20 \pm 2{ }^{\circ} \mathrm{C}$, relative humidity of $70-75 \%$, and light period of 12 hours at an intensity of $15 \mu \mathrm{M} \mathrm{m}^{-2} \mathrm{~s}^{-1}$ till the end of the experiment.

\section{Trait assessments}

Vase life. It was calculated by counting the days from the treatment of cut flowers with $\mathrm{Ce}\left(\mathrm{NO}_{3}\right)_{3}$ and $\mathrm{SA}$ until $50 \%$ wilting of florets (Cho et al., 2001).

Solution uptake. It was estimated by the procedure described in Kabari and Solimandarabi (2019). Accordingly, the initial solution volume $\left(\mathrm{V}_{\mathrm{t} 0}\right)$, final-day solution volume $\left(\mathrm{V}_{\mathrm{t} 1}\right)$, cut flower weight on the first day $(\mathrm{FW})$, and final surface evaporation from the solution $\left(\mathrm{E}_{t}\right)$ were calculated. It is worth noting that to calculate $\mathrm{E}_{\mathrm{t}}$, several vases containing $250 \mathrm{ml}$ distilled water were placed in different parts of the study site on the first day. The amount of water loss on the final day showed the rate of surface evaporation. Finally, the following equation was applied to estimate the rate of solution uptake in $\mathrm{mL} \mathrm{g}^{-1} \mathrm{FW}$ :

$$
\text { Solution uptake }(\mathrm{mL} / \mathrm{g} \mathrm{FW})=\frac{V_{t 0}-\left(E_{t}+V_{t 1}\right)}{F W}
$$

Vase solution pH. It was measured on the first and last days with a digital $\mathrm{CG} 824 \mathrm{pH}$-meter.

Bacteria population of the stem. Twenty-four hours after the treatments, a $2-\mathrm{cm}$ sample was taken from the end of the stem, was washed with distilled water, was crashed in a fully sterilized medium, and was diluted with $0.9 \%$ normal saline serum. Then, $0.1 \mathrm{~mL}$ of the solution was cultured on agar. Twenty-four hours after incubation of the samples at $37{ }^{\circ} \mathrm{C}$, the colonies of bacteria were counted (Liu et al., 2009).

Petal anthocyanin. It was measured by the procedure described in Jadid Solimandarabi et al. (2017) for which $0.5 \mathrm{~g}$ of fresh petal tissue was extracted with acidic ethanol on the fifth day. After filtration, the absorption by the extract was read at $535 \mathrm{~nm}$ with a JASCO Model V-530 spectrophotometer. Then, anthocyanin content was calculated in $\mathrm{mg} 100 \mathrm{~g}^{-1} \mathrm{FW}$ by the following equation:

$$
\text { Anthocyanin }(\mathrm{mg} / 100 \mathrm{~g} \mathrm{FW})=\frac{e \times b \times c}{d \times a} \times 100
$$

in which $e$ represents the sample weight, $b$ denotes the sample size, $c$ is the whole solution, $d$ is the volume of the taken sample, and $a$ is the spectrophotometer reading.

Total protein. The petals of lisianthus were sampled on the fifth day to determine their total protein content by Kjeldahl's indirect method. So, first nitrogen percentage and then protein percentage were calculated by the following equations:

$$
\text { Nitrogen }(\%)=0.56 \times t \times(a-b) \times \frac{V}{W} \times \frac{100}{D M}
$$

in which $t$ is the concentration of acid used for titration in mol L-1, $a$ is the amount of acid used for sample in $\mathrm{mol} \mathrm{L}^{-1}, b$ is the amount of acid used as a control in $\mathrm{ml}, v$ is the volume of extract taken from digestion in $\mathrm{ml}, w$ is the plant sample weight for digestion in $\mathrm{g}$, and $D M$ is the plant dry matter.

$$
\text { Total protein }(\%)=\text { nitrogen } \times 6.25
$$

Malondialdehyde (MDA). It was calculated by Heath and Parker's (1968) method. So, $0.5 \mathrm{~g}$ of petal tissue was sampled by liquefied nitrogen and potassium phosphate buffer. The extract was centrifuged at $4{ }^{\circ} \mathrm{C}$ at a speed of 14,000 and $10,500 \mathrm{rpm}$ and the supernatant was separated with a sampler. Then, $200 \mu \mathrm{L}$ of the supernatant was mixed with $1000 \mu \mathrm{l}$ of trichloroacetic acid (TCA) and thiobarbituric acid reactive substances (TBAS) and was heated in a hot water bath for 30 minutes. Immediately after that, the samples were placed in an ice-filled container for 30 minutes. The cooled mixture was centrifuged at $4{ }^{\circ} \mathrm{C}$ at $10,500 \mathrm{rpm}$ for 10 minutes. Then, it was read with a spectrophotometer at 532 and $600 \mathrm{~nm}$ and the readings were placed in the following equation to yield MDA content in $\mathrm{nmol} \mathrm{g}^{-1} \mathrm{FW}$.

$$
\operatorname{MDA}(\mathrm{nmol} / \mathrm{gFW})=\mathrm{A}_{532 \mathrm{~nm}}-\mathrm{A}_{600 \mathrm{~nm}}
$$

Peroxidase (POD) activity. It was measured by In et al. (2007) method for which some petal samples were detached from the flower branch on the fifth day and was extracted with $50 \mathrm{mM}$ of potassium phosphate buffer $(\mathrm{pH}$ 7.0). The extract was centrifuged at $10500 \mathrm{rpm}$ at $4{ }^{\circ} \mathrm{C}$ for 20 minutes. The supernatant was used as the enzymatic extract. So, $100 \mu \mathrm{L}$ of the extract was added with $450 \mu \mathrm{L}$ of $\mathrm{H}_{2} \mathrm{O}_{2}$ and $450 \mu \mathrm{L}$ of guaiacol solution. Then, it was read at $470 \mathrm{~nm}$ with a JASCO Model V-530 spectrophotometer and POD activity was reported in $\mathrm{nmol} \mathrm{g}^{-1} \mathrm{FW}$.

Ascorbate peroxidase (APX) enzyme activity. The sampling and extracting procedure was similar to that of POD activity. APX activity was measured by the method described in Nakano and Asada (1981). So, $150 \mu \mathrm{L}$ of the enzymatic extract was mixed with $50 \mathrm{mM}$ of potassium phosphate buffer, $0.5 \mathrm{mM}$ of ascorbate, and $0.1 \mathrm{mM}$ hydrogen peroxide. It was read at $290 \mathrm{~nm}$ with a JASCO Model V-530 spectrophotometer. APX activity was measured according to Nakano and Asada (1980). The reaction mixture contained $50 \mathrm{mM}(\mathrm{pH}$ 7.0) potassium phosphate buffer $(\mathrm{pH}$ 7.0) 0.1 $\mathrm{mM}$ EDTA, $0.25 \mathrm{mM}$ ascorbate, $1.0 \mathrm{mM} \mathrm{H}_{2} \mathrm{O}_{2}$, and 100 $\mathrm{mL}$ of the enzymes extract. $\mathrm{H}_{2} \mathrm{O}_{2}$-dependent oxidation of ascorbate was followed by a decrease in the absorbance at $290 \mathrm{~nm}$ with a JASCO Model V-530 spectrophotometer. The experiment was performed at $25^{\circ} \mathrm{C}$. The APX activity of the extract was expressed as activity $\mathrm{U} / \mathrm{g}$ FW min.

Polyphenol oxidase (PPO) enzyme activity. It was measured by Nicoli et al. (1991)'s method. The enzymatic 
extract was prepared same as POD enzyme. Then, a mixture was prepared of $100 \mu \mathrm{L}$ of enzymatic extract, $2.5 \mathrm{~mL}$ of potassium phosphate buffer (pH 6.8), $200 \mu \mathrm{l}$ of 0.02-M pyrogallol as the enzyme precursor (final volume reaction was $3 \mathrm{ml}$ ) and was read at $420 \mathrm{~nm}$ with a JASCO Model V-530 spectrophotometer. It was measured by Nicoli et al. (1991) method. The enzymatic extract was prepared similar to POD enzyme. Then, a mixture was prepared of 300 $\mu \mathrm{L}$ of enzymatic extract, $2.5 \mathrm{~mL}$ of potassium phosphate buffer (pH 6.8) $200 \mu \mathrm{l}$ of 0.02-M Pyrogallol as the enzyme precursor and was read at $420 \mathrm{~nm}$ with a JASCO Model V-530 spectrophotometer. The PPO activity of the extract was expressed as activity unit/g FW min.

\section{Data analysis}

Data of the daily visits and laboratory assays were analyzed in the SPSS software package. The LSD test was applied for the comparison of data means.

\section{Results}

\section{Vase life}

The effect of the treatments was significant $(p<0.01)$ on the vase life of lisianthuses (Table 1). $\mathrm{Ce}\left(\mathrm{NO}_{3}\right)_{3}$ at all four levels and SA at the rates of 50 and $100 \mathrm{mg} \mathrm{L}^{-1}$ improved the vase life versus the control (11.63 days).

The most effective treatments were $40 \mu \mathrm{M} \mathrm{Ce}\left(\mathrm{NO}_{3}\right)_{3}$ (15.42 days) and $100 \mathrm{mg} \mathrm{L}^{-1} \mathrm{SA}$ (15.20 days), which did not differ from $50 \mathrm{mg} \mathrm{L}^{-1} \mathrm{SA}$ (14.78 days) significantly. The flowers treated with $200 \mathrm{mg} \mathrm{L}^{-1} \mathrm{SA}$ exhibited the shortest vase life of 10.63 days, reflecting the negative and toxic effect of higher levels of SA on the longevity of lisianthus cut flowers. The application of $\mathrm{Ce}\left(\mathrm{NO}_{3}\right)_{3}$ at the rates of 80 and $200 \mu \mathrm{M}$ resulted in the loss of the vase life as compared to its application at the rates of 20 and $40 \mu \mathrm{M}$; however, the former two levels improved the vase life when compared to the control (Figure 1).

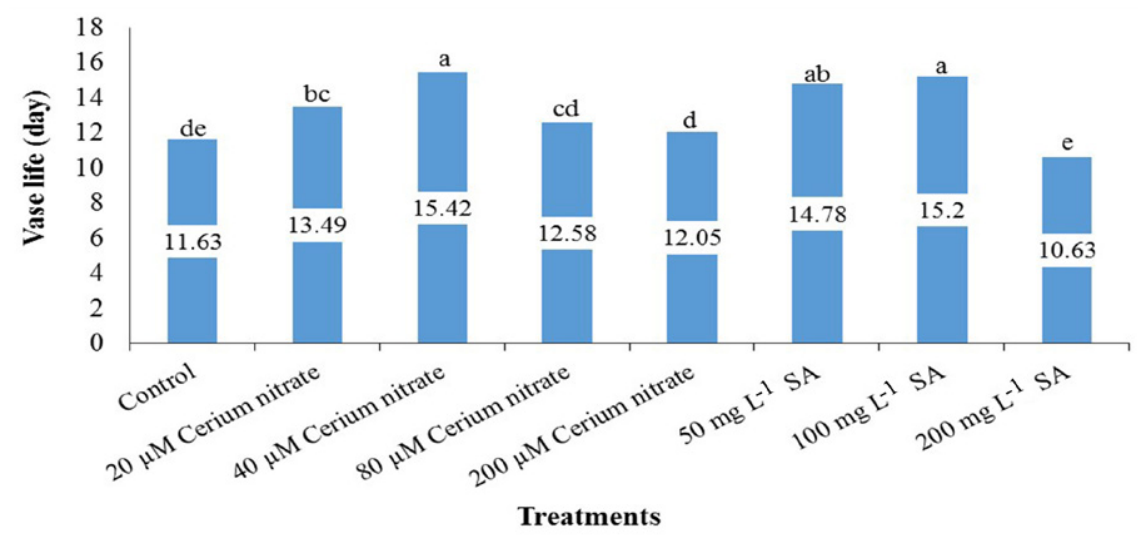

Figure 1. The effect of different rates of salicylic acid and cerium nitrate on the vase life of the cut lisianthus flowers.

\section{Solution uptake}

The solution uptake of the lisianthus cut flowers were improved by the treatments significantly $(p<0.01)$. The highest solution uptake was $1.48 \mathrm{~mL} \mathrm{~g}^{-1} \mathrm{FW}$ observed in the flowers treated with $100 \mathrm{mg} \mathrm{l}^{-1} \mathrm{SA}$ and $1.43 \mathrm{~mL} \mathrm{~g}^{-1} \mathrm{FW}$ observed in the flowers treated with $40 \mu \mathrm{M} \mathrm{Ce}\left(\mathrm{NO}_{3}\right)_{3}$. These two treatments did not show any significant differences with one another. The treatment of $200 \mathrm{mg} \mathrm{L}^{-1} \mathrm{SA}$, which exhibited the shortest vase life, exhibited the lowest rate of solution uptake (1.02 $\left.\mathrm{mL} \mathrm{g}^{-1} \mathrm{FW}\right)$ too (Table 2). 
Table 1. Analysis of variance for the effect of different treatments on the measured traits

\begin{tabular}{|c|c|c|c|c|c|c|c|c|c|c|c|c|}
\hline SoV & df & Vase life & $\begin{array}{l}\text { Solution } \\
\text { uptake }\end{array}$ & $\begin{array}{c}\text { Bacterial } \\
\text { population } \\
\text { at stem end }\end{array}$ & $\begin{array}{c}\text { Total } \\
\text { anthocyanin }\end{array}$ & First day pH & Last day $\mathrm{pH}$ & $\begin{array}{c}\text { Total } \\
\text { protein }\end{array}$ & MDA & PPO & APX & POD \\
\hline Replication & 2 & $0.428^{\mathrm{ns}}$ & $0.00280^{\mathrm{ns}}$ & $260^{\mathrm{ns}}$ & $16720^{\text {ns }}$ & $0.736^{\mathrm{ns}}$ & $0.488^{\text {ns }}$ & $3.125^{\mathrm{ns}}$ & $6.125^{\mathrm{ns}}$ & $0.00000554^{*}$ & $12.5^{\text {ns }}$ & $0.00000112^{\mathrm{ns}}$ \\
\hline Treatment & 7 & $9.557^{* *}$ & $0.0768^{* *}$ & $3550^{*}$ & $1023584^{* *}$ & $9.83^{* *}$ & $6.403^{* *}$ & $21.21^{*}$ & $57.7^{*}$ & $0.00000702^{* *}$ & $239^{* *}$ & $0.00016264^{* *}$ \\
\hline Error & 14 & 0.633 & 0.005109 & 915 & 19893 & 0.4812 & 0.3647 & 5.4107 & 17.55 & 0.00000154 & 12.5 & 0.00002112 \\
\hline CV (\%) & & 6.01 & 5.687 & 23.06 & 15.68 & 14.86 & 11.94 & 21.27 & 17.43 & 10.27 & 21.7 & 19.35 \\
\hline
\end{tabular}

",** and ${ }^{\text {ns: }}$ Significant at $\mathrm{P}<0.05, \mathrm{P}<0.01$ and insignificant respectively.

Table 2. Means comparison for the effect of different treatments on the measured traits.

\begin{tabular}{|c|c|c|c|c|c|c|c|c|c|c|c|}
\hline Treatments & $\begin{array}{c}\text { Vase life } \\
\text { (day) }\end{array}$ & $\begin{array}{c}\text { Solution } \\
\text { uptake } \\
\left(\mathbf{m L ~ g ^ { - 1 }} \mathbf{F W}\right)\end{array}$ & $\begin{array}{c}\text { Bacterial population } \\
\text { in stem end } \\
\left(\log _{10} \mathrm{CFU} \mathrm{ml} \mathrm{ml}^{-1}\right)\end{array}$ & $\begin{array}{c}\text { Total } \\
\text { anthocyanin } \\
\left(\mathbf{m g ~} 100 \mathrm{~g}^{-1} \text { F.W. }\right)\end{array}$ & $\begin{array}{c}\text { First day } \\
\text { pH }\end{array}$ & $\begin{array}{c}\text { Last day } \\
\text { pH }\end{array}$ & $\begin{array}{c}\text { Total } \\
\text { protein } \\
(\%)\end{array}$ & $\begin{array}{c}\text { MDA } \\
\left(\mathrm{nmol} \mathrm{g}^{-1}\right. \\
\text { F.W. })\end{array}$ & $\begin{array}{c}\text { PPO } \\
\left(\text { IU g } \text { g }^{-1} \text { F.W. }\right)\end{array}$ & $\begin{array}{c}\text { APX } \\
\left(\mathrm{IU} \mathrm{g}^{-1} \text { F.W. }\right)\end{array}$ & $\begin{array}{c}\text { POD } \mid \\
\left(\text { nmol g }^{-1} \text { F.W. }\right)\end{array}$ \\
\hline Control & $11.63 \mathrm{de}$ & $1.11 \mathrm{de}$ & $161.3 \mathrm{ab}$ & $655 \mathrm{c}$ & $6.11 \mathrm{a}$ & $6.59 \mathrm{a}$ & $8.13 \mathrm{~cd}$ & $28.30 \mathrm{ab}$ & $0.013 \mathrm{a}$ & $7.350 \mathrm{c}$ & $0.020 \mathrm{~b}$ \\
\hline $20 \mu \mathrm{M} \mathrm{Ce}\left(\mathrm{NO}_{3}\right)_{3}$ & $13.49 \mathrm{bc}$ & $1.13 \mathrm{de}$ & $113.6 \mathrm{bc}$ & $559 \mathrm{~cd}$ & $6.15 \mathrm{a}$ & $6.36 \mathrm{ab}$ & $10.92 a b c$ & $24.44 \mathrm{abc}$ & $0.012 b c$ & $11.50 \mathrm{bc}$ & $0.020 \mathrm{~b}$ \\
\hline $40 \mu \mathrm{M} \mathrm{Ce}\left(\mathrm{NO}_{3}\right)_{3}$ & $15.42 \mathrm{a}$ & $1.43 \mathrm{ab}$ & $81.3 \mathrm{c}$ & $1161 \mathrm{~b}$ & $5.74 \mathrm{a}$ & $5.63 \mathrm{abc}$ & $13.93 \mathrm{a}$ & $18.65 \mathrm{c}$ & $0.011 \mathrm{bc}$ & $29.40 \mathrm{a}$ & $0.041 \mathrm{a}$ \\
\hline $80 \mu \mathrm{M} \mathrm{Ce}\left(\mathrm{NO}_{3}\right)_{3}$ & $12.58 \mathrm{~cd}$ & $1.31 \mathrm{bc}$ & $128.3 \mathrm{bc}$ & $1635 \mathrm{a}$ & $6.05 \mathrm{a}$ & $5.49 \mathrm{bc}$ & $12.80 \mathrm{ab}$ & $21.86 b c$ & $0.012 b c$ & $17.05 \mathrm{~b}$ & $0.021 \mathrm{~b}$ \\
\hline $200 \mu \mathrm{M} \mathrm{Ce}\left(\mathrm{NO}_{3}\right)_{3}$ & $12.05 \mathrm{~d}$ & $1.23 \mathrm{~cd}$ & $156.3 \mathrm{ab}$ & $588 \mathrm{c}$ & $5.80 \mathrm{a}$ & $5.82 \mathrm{ab}$ & $9.52 \mathrm{bcd}$ & $27.65 \mathrm{ab}$ & $0.012 \mathrm{bc}$ & $11.85 \mathrm{bc}$ & $0.023 \mathrm{~b}$ \\
\hline $50 \mathrm{mg} \mathrm{L}^{-1} \mathrm{SA}$ & $14.78 \mathrm{ab}$ & $1.32 \mathrm{bc}$ & $110.0 \mathrm{bc}$ & $423 \mathrm{~cd}$ & $2.75 \mathrm{~b}$ & $4.70 \mathrm{c}$ & $12.06 \mathrm{abc}$ & $22.51 b c$ & $0.011 \mathrm{bc}$ & $15.30 \mathrm{~b}$ & $0.021 \mathrm{~b}$ \\
\hline $100 \mathrm{mg} \mathrm{L}^{-1} \mathrm{SA}$ & $15.20 \mathrm{a}$ & $1.48 \mathrm{a}$ & $110.6 \mathrm{bc}$ & $1872 \mathrm{a}$ & $2.41 \mathrm{~b}$ & $3.44 \mathrm{~d}$ & $13.54 \mathrm{ab}$ & $18.65 \mathrm{c}$ & $0.010 \mathrm{c}$ & $30.00 \mathrm{a}$ & $0.026 \mathrm{~b}$ \\
\hline $200 \mathrm{mg} \mathrm{L}^{-1} \mathrm{SA}$ & $10.63 \mathrm{e}$ & $1.02 \mathrm{e}$ & $187.0 \mathrm{a}$ & $322 \mathrm{~d}$ & $2.30 \mathrm{~b}$ & $2.40 \mathrm{~d}$ & $6.56 \mathrm{~d}$ & $30.23 \mathrm{a}$ & $0.015 \mathrm{a}$ & $7.70 \mathrm{c}$ & $0.018 \mathrm{~b}$ \\
\hline
\end{tabular}

*In each column, means with the similar letters are not significantly different $(p<0.05)$ using the LSD test. 


\section{The bacterial population at the stem end}

The effect of different treatments was found to be significant $(p<0.05)$ on the bacterial population at the stem end (Table 1). The most population bacterial colony (187 $\log _{10}$ CFU mL $\mathrm{mL}^{-1}$ ) was related to the flowers treated with $200 \mathrm{mg} \mathrm{L}^{-1} \mathrm{SA}$, insignificantly differing from that of the plants treated with $200 \mu \mathrm{M} \mathrm{Ce}\left(\mathrm{NO}_{3}\right)_{3}$ and the control. The most successful treatments in reducing the microbial load at the stem end were $40 \mu \mathrm{M} \mathrm{Ce}\left(\mathrm{NO}_{3}\right)_{3}\left(81.3 \log _{10} \mathrm{CFU} \mathrm{mL}{ }^{-1}\right)$, $50 \mathrm{mg} \mathrm{L}^{-1} \mathrm{SA}$, and $100 \mathrm{mg} \mathrm{L}^{-1} \mathrm{SA}$, respectively (Table 2).

\section{Vase solution pH}

According to the results of variance analysis, the effect of the treatments was significant $(p<0.01)$ on the first-day and last-day vase solution $\mathrm{pH}$ (Table 1). The $\mathrm{pH}$ of the SAcontaining vase solution on both the first and last days was lower than that of the control and the solutions containing different levels of $\mathrm{Ce}\left(\mathrm{NO}_{3}\right)_{3}$. Overall, the vase solution $\mathrm{pH}$ was lower than 7 , which is the appropriate $\mathrm{pH}$ for vase solutions, in all treatments (Table 2).

\section{Petal protein}

The results revealed that the total protein content in the petals of the lisianthuses was significantly $(p<0.05)$ decreased when they were subjected to $200 \mathrm{mg} \mathrm{L}^{-1} \mathrm{SA}$ $(6.56 \%)$. As is evident in Table 2, $20 \mu \mathrm{M} \mathrm{Ce}\left(\mathrm{NO}_{3}\right)_{3}$ was related to the highest petal content of $13.93 \%$, but it did not differ from that of 50 and $100 \mathrm{mg} \mathrm{L}^{-1} \mathrm{SA}$ and 20 and $80 \mu \mathrm{M}$ $\mathrm{Ce}\left(\mathrm{NO}_{3}\right)_{3}$ significantly (Table 2 ).

\section{Petal anthocyanin content}

The effect of the treatments was significant $(p<0.01)$ on the petal anthocyanin content (Table 1). Table 2 displays that the highest petal anthocyanin content was observed in the plants treated with $100 \mathrm{mg} \mathrm{L}^{-1} \mathrm{SA}\left(1,872 \mathrm{mg} 100 \mathrm{~g}^{-1} \mathrm{FW}\right)$ and those treated with $80 \mu \mathrm{M} \mathrm{Ce}\left(\mathrm{NO}_{3}\right)_{3}\left(1,635 \mathrm{mg} 100 \mathrm{~g}^{-1} \mathrm{FW}\right)$. The application of $200 \mathrm{mg} \mathrm{L}^{-1} \mathrm{SA}$ resulted in the lowest petal anthocyanin among all the treatments (Table 2).

\section{MDA content}

The effect of the treatments was significant $(p<0.05)$ on the peroxidation of lipids or MDA (Table 1). The highest rate of MDA accumulation was related to the flowers treated with $200 \mathrm{mg} \mathrm{L}^{-1} \mathrm{SA}\left(30.23 \mathrm{nmol} \mathrm{g}^{-1} \mathrm{FW}\right)$, but it did not show significant differences from that of the control and the flowers treated with 20 and $200 \mu \mathrm{M} \mathrm{Ce}\left(\mathrm{NO}_{3}\right)_{3}$. The treatments of $40 \mu \mathrm{M} \mathrm{Ce}\left(\mathrm{NO}_{3}\right)_{3}$ and $100 \mathrm{mg} \mathrm{L}^{-1} \mathrm{SA}^{2}(18.65$ nmol g-1 FW) both performed the best in controlling lipid peroxidation and reducing MDA accumulation (Table 2).

\section{Enzyme peroxidase (POD)}

Based on the results, the application of $40 \mu \mathrm{M} \mathrm{Ce}\left(\mathrm{NO}_{3}\right)_{3}$ increased peroxidase activity significantly $(p<0.01)$ as compared to the control. The lowest activity of this enzyme $\left(0.018 \mathrm{nmol} \mathrm{g}^{-1} \mathrm{FW}\right)$ was obtained from the application of $200 \mathrm{mg} \mathrm{L}^{-1} \mathrm{SA}$, which was not significantly different from that of the control and the treatments of $20,80,200 \mu \mathrm{M}$ $\mathrm{Ce}\left(\mathrm{NO}_{3}\right)_{3}$ and 50 and $100 \mathrm{mg} \mathrm{L}^{-1} \mathrm{SA}$ (Table 2).

\section{Enzyme ascorbate peroxidase (APX)}

APX activity was significantly $(p<0.01)$ increased when the flowers were treated with $100 \mathrm{mg} \mathrm{L}^{-1} \mathrm{SA}\left(30 \mathrm{IU} \mathrm{g}^{-1} \mathrm{FW}\right)$ and $40 \mu \mathrm{M} \mathrm{Ce}\left(\mathrm{NO}_{3}\right)_{3}\left(29.40 \mathrm{IU} \mathrm{g}^{-1} \mathrm{FW}\right)$. The lowest APX activity (7.35 $\mathrm{IU} \mathrm{g}^{-1} \mathrm{FW}$ ) was related to the control, but not differing from that of $200 \mathrm{mg} \mathrm{L}^{-1}$ SA significantly (Table 2).

\section{Enzyme polyphenol oxidase (PPO)}

The effect of the treatments was found to be significant $(p<0.01)$ on PPO activity (Table 2$)$. The highest activity was observed in the plants treated with $200 \mathrm{mg} \mathrm{L}^{-1} \mathrm{SA}$ (0.015 IU g- $\mathrm{IW}^{-1}$ ) and the control (0.013 $\left.\mathrm{IU} \mathrm{g}^{-1} \mathrm{FW}\right)$ and the lowest was $0.010 \mathrm{IU} \mathrm{g}^{-1} \mathrm{FW}$ observed in those treated with $200 \mathrm{mg} \mathrm{L}^{-1} \mathrm{SA}$ (Table 2).

\section{Discussion}

Salicylic acid (SA) and cerium nitrate $\left[\mathrm{Ce}\left(\mathrm{NO}_{3}\right)_{3}\right]$ were recognized as compounds that prolong vase life and escalate the relevant traits in cut lisianthus flowers. As was already mentioned within the results, higher rates of the applied compounds, especially SA at the rate of $200 \mathrm{mg} \mathrm{L}^{-1}$, had a negative and toxic effect on the vase life and related traits. SA increases hydrogen peroxide and oxygen free radicals to induce resistance in plants in the early stages of stress. These compounds are gradually eliminated by the enzymatic and non-enzymatic defense systems of the plant (Rohi et al., 2010). Due to the increased peroxidation of lipids with the use of $200 \mathrm{mg} \mathrm{L}^{-1} \mathrm{SA}$, it seems that the application of high concentrations of SA has caused the overproduction of oxygen radicals and oxidative stress that the plant's antioxidant system is able to control of these factors is not destructive and ultimately causes tissue damage and reduced vase life. The toxic effect is to increase lipid peroxidation (MDA) and reduce vase life. This is probably due to the increase in $\mathrm{H}_{2} \mathrm{O}_{2}$ and free radicals. Asghari and Aghdam (2010) argue that the appropriate and non-toxic concentration of SA should be specified for each crop through frequent experiments and trials. In the study of Geriloo and Ghasemnezhad (2011), the application of $150 \mathrm{mg} \mathrm{L}^{-1} \mathrm{SA}$ increased the vase life of cut rose 'Yellow Island', but its increase to $200 \mathrm{mg} \mathrm{L}^{-1}$ had negative impacts on the measured traits. Negative effects of reduced vase life include premature wilting of petals and increased lipid peroxidation. Also, Kazemi et al. (2011) showed that the vase life of lisianthuses was significantly extended with the application of $2 \mathrm{mM}$ SA, but when SA was applied at the rate of $4 \mathrm{mM}$, the vase life was shortened. Moreover, Cavasini et al. (2015) found that a dose of $1000 \mathrm{mg} \mathrm{L}^{-1}$ of SA was detrimental to the vase life of cut lisianthus. The negative effect of high levels of SA on the vase life and related traits has also reported for cut carnation (Kazemi et al., 2011) and chrysanthemum (Mansouri, 2012), which is consistent with our findings.

In addition to high rates of $\mathrm{SA}, \mathrm{Ce}\left(\mathrm{NO}_{3}\right)_{3}$ at the rates of 80 and $100 \mu \mathrm{M}$ performed poorly in improving the quantitative and qualitative traits of the cut lisianthus flowers as compared to 20 and $40 \mu \mathrm{M}$. Although these treatments 
outperformed the control in most cases, the findings may show the negative impact of higher concentrations of $\mathrm{Ce}\left(\mathrm{NO}_{3}\right)_{3}$ on the longevity of cut lisianthus flowers. The negative effect of high $\mathrm{Ce}\left(\mathrm{NO}_{3}\right)_{3}$ rates have also been reported on the longevity of cut Lilium (Houa et al., 2018) and rose flowers (Wang et al., 2017), which is in agreement with our findings.

It has been shown that the vase solution $\mathrm{pH}$ is a determinant factor dictating solution uptake by cut flowers. The best $\mathrm{pH}$ for vase solutions has been found to be $<7$ (Nell, 2002; Edrisi, 2009). In our study, all the treatments had $\mathrm{pH}<7$, and the lowest was for SA treatments.

Vascular blockage by microorganisms is a major factor implicated for short postharvest longevity of cut flowers. In the present study, the microbial load at the stem end was decreased with the application of $\mathrm{Ce}\left(\mathrm{NO}_{3}\right)_{3}$ and SA at lower rates, which was followed by the increased uptake of water. Since the vividness of cut flowers is directly related to water uptake, the positive effect of $\mathrm{SA}$ and $\mathrm{Ce}\left(\mathrm{NO}_{3}\right)_{3}$ on improving the vase life of cut lisianthus flowers can be attributed to their capability in suppressing microbial load at stem ends and establishing balance in water uptake.

Researchers argue that SA is an antibacterial compounds that prolongs the vase life of cut flowers by reducing the growth and propagation of microorganisms and inhibiting vascular blockage (Mori et al., 2001; Alaey et al., 2011). In addition to the antibacterial activity of SA, its association has been reported in controlling stomatal movements, regulating evapotranspiration, adjusting aging-related genes, controlling oxidative stresses, and finally, improving the longevity of horticultural products (Mori et al., 2001; Asghari and Aghdam, 2010; Alaey et al., 2011).

In the study of Alaey et al. (2011), it was found that the application of SA to the vase solution of rose 'Black Magic' cut flowers improved postharvest longevity through increasing water uptake. Bayat and Aminifard (2017) obtained the longest vase life of the cut flowers of alstroemeria, gerbera, Lilium, rose, and tuberose by applying $300 \mathrm{mg} \mathrm{L}^{-1} \mathrm{SA}$. They attributed the positive effect of SA on the vase life of cut flowers to its impact on preserving water uptake and its antioxidative property. There are reports on the improvement of vase life and the related traits in the cut flowers of lisianthuses and carnations (Kazemi et al., 2011) and chrysanthemums (Mansouri, 2012; Mashhadian et al., 2012) when SA is applied at lower rates, which is consistent with our findings.

Cerium is an antibiotic (Huang, 2002) and antioxidant (He and Loh, 2000; Yin et al., 2009) whose positive effect in the form of $\mathrm{Ce}\left(\mathrm{NO}_{3}\right)_{3}$ has been reported on the postharvest longevity of cut carnations (Zheng and Guo, 2018) and roses (Wang et al., 2017). Houa et al. (2018) reported that the application of $\mathrm{Ce}\left(\mathrm{NO}_{3}\right)_{3}$ in the vase solution of Lilium cut flowers prolonged their postharvest longevity by enhancing water uptake and influencing the ASA-GSH cycle. The glutathione ascorbate cycle is one of the enzymatic defense systems of plants in purifying reactive oxygen species and maintaining membrane stability under stress. Ascorbate peroxidase, 1,2-hydroascorbate reductase and glutathione reductase are some of the enzymes in this cycle that play an important role in the clearance of hydrogen peroxide and reactive oxygen species (Zheng and Guo, 2018; Mittler and Zilinskas, 1994). Cerium is effective in increasing the activity of enzymes in this cycle (Zheng and Guo, 2018; Wang et al., 2017).

The senescence of cut flowers is associated with MDA content and the extent of lipid peroxidation so that MDA content increases as a cut flower approaches the end of its vase life (Shan and Zhao, 2015; Song et al., 2014). In our experiment, the treatments that exhibited longer vase life had lower MDA content. It has been documented that SA reduces lipid peroxidation by scavenging ROS and adjusting the activity of antioxidant enzymes (Ezhilmathi et al., 2007). Kazemi et al. (2011) reported that when SA was applied, MDA accumulation was decreased in cut lisianthus flowers, which is similar to our finding. In the study of Mansouri (2012), the treatment of cut chrysanthemum flowers with 0.1 and $1 \mu \mathrm{M}$ SA reduced MDA accumulation, but the application of 10 and $100 \mu \mathrm{M}$ SA increased it and influenced the postharvest longevity of the cut flowers adversely. In the present study, SA reduced MDA at the rates of 50 and $100 \mathrm{mg} \mathrm{L}^{-1}$, but when it was increased to $200 \mathrm{mg} \mathrm{L}^{-1}$, MDA accumulation was increased in the petals. Therefore, it can be concluded that the application of SA at high rates had a toxic impact on the lipids of the membrane and reduced the vase life of cut lisianthus flowers by increasing MDA accumulation.

$\mathrm{Ce}\left(\mathrm{NO}_{3}\right)_{3}$ inhibited lipid peroxidation or MDA accumulation in the petals of lisianthus and preserved the cut flowers for a longer time. The positive effect of $\mathrm{Ce}\left(\mathrm{NO}_{3}\right)_{3}$ on reducing MDA accumulation has been reported for the cut flowers of Liliums (Houa et al., 2018) and carnations (Zheng and Guo, 2018) too, which is similar to our findings. Wang et al. (2017) attributed the effect of $\mathrm{Ce}\left(\mathrm{NO}_{3}\right)_{3}$ on prolonging the vase life of cut rose flowers to the preservation of membrane structure through reducing lipid peroxidation and MDA accumulation.

The antioxidant enzymes were more active in the cut lisianthus flowers that had longer vase life. Antioxidant systems play a remarkable role in hindering the destructive effects of stresses and ROS in plants. POD and APX are antioxidant systems whose increased activity retards senescence (Shan and Zhao, 2015, Ataii et al., 2017). During petal aging and stress occurrence, the production of reactive oxygen species such as hydroxide radicals, hydrogen peroxide and superoxide anions increases in the plant. Accumulation of these molecules in the cell causes oxidative stress and damage to membranes and other macromolecules, leading to plant death. Plants use a variety of defense systems, including an antioxidant defense system against oxygen free radicals. Therefore, under stress conditions, the antioxidant defense capacity increases. SOD, CAT, PO, APX, etc. are among the antioxidant enzymes that protect the plant against damage caused by oxidative stress. These enzymes purify and remove reactive oxygen species. In fact, antioxidant enzymes oxidize by giving electrons to their oxygen free radicals and neutralize the oxidizing power of active oxygen species, thus preventing oxidative damage and the natural process of plant growth. They maintain the natural process of plant growth (Rohi et al., 2010; Carlos et al., 1996; Mittler, 2002). 
Researchers argue that SA is directly or indirectly involved in activating antioxidant enzymes (Tian et al., 2007). In indirect method, SA stimulates the antioxidant defense system in plants by producing hydrogen peroxide and oxygen free radicals. These destructive species are easily removed by the antioxidant system. In direct method, SA is able to decompose oxygen free radicals. Hassan and Ali (2014) reported that the treatment of cut gladiolus flowers with SA enhanced the activity of antioxidant enzymes and reduced the rate of aging. The increased activity of antioxidant enzymes and the lower rate of ROS synthesis have been reported in cut rose flowers treated with SA (Capdeville et al., 2003). Consistent with our findings, there are also reports on the favorable effect of $\mathrm{Ce}\left(\mathrm{NO}_{3}\right)_{3}$ on increasing the activity of antioxidant enzymes in cut flowers of roses (Wang et al., 2017), carnations (Wu et al., 2014), and Liliums (Houa et al., 2018).

By accelerating the oxidation of phenols, PPO increases rotting and browning of tissues during storage. If the activity of this enzyme can be reduced in some way, postharvest longevity and quality can be improved (Ali Pour et al., 2015). PPO is a strong oxidizer of phenols and its activity in plants increases with the occurrence of biotic and abiotic stresses (Mayer and Harel, 1979). Reducing the activity of this enzyme with postharvest life-prolonging compounds such as nitric oxide (Ali Pour et al., 2015), heat treatment (Dogan and Dogan, 2004), pH-reducing agents (Kang and Yu, 2005), etc. can reduce tissue browning and reduce vase life. As already mentioned in the Results section, the PPO activity was lower in the flowers that had longer vase life. In fact, the application of SA and $\mathrm{Ce}\left(\mathrm{NO}_{3}\right)_{3}$ inhibited the destructive activity of PPO during storage. The application of cerium alleviated the activity of PPO in the study of Shyam and Aery (2012). Sadeghi et al. (2017) reported that the application of longevitypromoting compounds to cut Alstroemeria flowers reduced PPO activity, which agrees with our findings. As the petals age, the production of proteins that are responsible for the breakdown of macromolecules increases. On the other hand, the production and activity of ROSs cause the breakdown of proteins and lipids (Eason and Webster, 1995; Lay Yee et al., 1992; Sood et al., 2006). In general, due to the imbalance between the production and degradation of proteins during stress and aging, the amount of protein in tissues generally decreases. In the present study, the amount of protein was lower in the treatments that had a shorter vase life. Due to the effect of cerium nitrate and SA in maintaining the vase life, it seems that these compounds delay the aging process and preserve the proteins in this cut flower. Delay in aging and preservation of proteins with the use of SA in this study has been reported (Bahrami et al., 2013), which is consistent with the results of the present study. Anthocyanins are antioxidant compounds belonging to the group of flavonoids that are directly involved in the breakdown of reactive oxygen species and reduce the damaging effects of stress. In the present study, the highest amount of petal anthocyanin belonged to the treatment of $100 \mathrm{mg} \mathrm{L}^{-1} \mathrm{SA}$ and $80 \mathrm{mM}$ cerium nitrate, which can indicate the positive effect of these compounds in maintaining the activity of antioxidants and delaying aging. SA has been shown to increase the production of the enzyme phenylalanine ammonialyase, which is responsible for the biosynthesis of flavonoids (Chen et al., 2006; Lu et al., 2011). Increasing the amount of anthocyanins with the use of SA in gladiolus (Rahmani et al., 2015) and increasing the accumulation of anthocyanins in potato seedlings by affecting the expression of genes involved in the synthesis of anthocyanins has been reported with the use of cerium (Qineng et al., 2006), which agrees with the results of the present study.

\section{Conclusions}

In conclusion, we found that the application of SA and $\mathrm{Ce}\left(\mathrm{NO}_{3}\right)_{3}$ at lower rates improved the quantitative and qualitative traits of the cut lisianthus flowers. But, their higher concentrations, especially SA at the rate of 200 $\mathrm{mg} \mathrm{L}{ }^{-1}$, were detrimental to the postharvest traits of the cut flowers. Thus, it is recommended to use appropriate concentrations of SA (50 and $\left.100 \mathrm{mg} \mathrm{L}^{-1}\right)$ and $\mathrm{Ce}\left(\mathrm{NO}_{3}\right)_{3}(40$ $\mu \mathrm{M})$ to preserve the quantitative and qualitative traits of cut flowers of lisianthus 'Pink Picotee'. Aging in cut flowers is associated with the continuous production of high levels of oxygen free radicals. Antioxidant enzymes prevent oxidative stress and damage to membranes by inhibiting reactive oxygen species, thereby preventing premature aging of flowers.

\section{Authors contributions}

DH: conceived the study, planned the experiments and analysed the data. FP: performed the experiments. BK: conceived the study, planned the experiments and analysed the data, manuscript write and review.

\section{References}

ALAEY, M.; BABALAR, M.; NADERI, R.; KAFI, M. Effect of pre and postharvest salicylic acid treatment on physio-chemical attributes in relation to vase life of rose cut flowers. Postharvest Biology and Technology, v.61, n.1, p.91-94, 2011. DOI: https://doi.Org/10.1016/j. postharvbio.2011.02.002

ALI POUR, S.; NASIBI, F.; FARAHMAND, H. Effect of different concentrations of sodium nitroprusside on physiological characteristics and the vase life of cut flowers of tuberose (Polianthes tuberosa L.). Journal of Plant Research, v.27, n.5, p.904-914, 2015.

ASGHARI, M.R.; AGHDAM, M.S. Impact of salicylic acid on postharvest physiology of horticultural crops. Trends in Food Science and Technology, v.21, n.10, p.502-509, 2010. DOI: https://doi.org/10.1016/j.tifs.2010.07.009 
ATAII, D.; NADERI, R.; KHANDAN MIRKOHI, A. Impact of preharvest putrescine treatment on quantitative, qualitative traits and postharvest vase life of lisianthus (Eustoma grandiflorum cv. Miarichi Grand white) cut flowers. Iranian Journal of Horticultural Science, v.48, n.2, p.229-242, 2017.

BAHRAMI, S.N.; ZAKIZADEH, H.; HAMIDOGHLI, Y.; GHASEMNEZHAD, M. Salicylic acid retards petal senescence in cut lisianthus (Eustoma grandiflorum 'Miarichi Grand White') flowers. Horticulture, Environment, and Biotechnology, v.54, p.519-523, 2011. https://doi.org/10.1007/s13580-013-1058-y

BAYAT, H.; AMINIFARD, M.H. Salicylic acid treatment extends the vase life of five commercial cut flowers. Electronic Journal of Biology, v.13, n.1, p.67-72, 2017.

CAVASINI, R.; LASCHI, D.; FAVERO, B.T.; LIMA, G.P.P. Lisianthus vase life after 1-methylcyclopropene and salicylic acid postharvest treatment. Acta Horticulturae, v.1060, p.109-113, 2015. DOI: https://doi.org/10.17660/ ActaHortic.2015.1060.14

CARlOS, G.; BARTOLI, M.; MONTALDI, S.E.; PUNTARULO, S. Oxidative stress, antioxidant capacity and ethylene production during ageing of cut carnation (Dianthus caryophyllus) petals. Journal of Experimental Botany, v.47, p.595-601, 1996. https://doi.org/10.1093/jxb/47.4.595

CAPDEVILLE, G.D.; MAFFIA, L.A.; FINGER, F.L.; BATISTA, U.G. Gray mold severity and vase life of rose buds after pulsing with citric acid, salicylic acid, calcium sulfate, sucrose and silver thiosulfate. Fitopatologia Brasileira, v.28, n.4, p.380-385, 2003. DOI: http://dx.doi. org/10.1590/S0100-41582003000400006

CHEN, J.Y.; WEN, P.F.; KONG, W.F.; PAN, Q.H.; ZHAN, J.C.; LI, J.M.; WAN, S.B.; HUANG, W.D. Effect of salicylic acid on phenylpropanoids and phenylalanine ammonia-lyase in harvested grape berries. Postharvest Biology and Technology, v.40, p.64-72, 2006. DOI: https://doi.org/10.1016/j.postharvbio.2005.12.017

CHO, M.S.; CELIKEL, F.G.; DODGE, L.; REID, M.S. Sucrose enhances the postharvest quality of cut flowers of Eustoma grandiflorum (Raf.) Shinn. Acta Horticulturae, n.543, 2001. DOI: https://doi.org/10.17660/ ActaHortic.2001.543.37

DING, C.K.; WANG, C.Y.; GROSS, K.C. Jasmonate and salicylate induce the expression of pathogenesis-related protein genes and increase resistance to chilling injury in tomato fruit. Planta, v.214, n.6, p.895-901, 2002. DOI: https://doi.org/10.1007/s00425-001-0698-9
DOGAN, S.; DOGAN, M. Determination of kinetic properties of polyphenol oxidase from Thymus (Thymus longicauliss sp. Chaubardii var. chaubardii). Food Chemistry, v.88, p.69-77, 2004. DOI: https://doi. org/10.1016/j.foodchem.2003.12.025

EASON, J.R.; WEBSTER, D. Development and senescence of Sandersonia aurantiaca (Hook.) flowers. Scientia Horticulturae, v.63, p.113-121, 1995. https://doi. org/10.1016/0304-4238(95)00796-V

EDRISI, B. Postharvest physiology of cut flowers. Arak: Payam-e Digar Publication., 2009. 150p.

EZHILMATHI, K.; SINGH, V.P.; ARORA, A.; SAIRAM, R.K. Effect of 5-sulfosalicylic acid on antioxidant activity in relation to vase life of Gladiolus cut flowers. Plant Growth Regulation, v.51, n.2, p.99-108, 2007. DOI: https://doi.org/10.1007/s10725-006-9142-2

GERAILOO, S.; GHASEMNEZHAD, M. Effect of salicylic acid on antioxidant enzyme activity and petal senescence in 'Yellow Island' cut rose flowers. Journal of Fruit and Ornamental Plant Research, v.19, n.1, p.183$193,2011$.

HARBAUGH, B.K. Lisianthus. In: ANDERSON, N.O. (eds). Flower Breeding and Genetics. Dordrecht, Springer, 2007. 644-663p.

HASSAN, F.; ALI, E. Protective effects of 1-methyl cyclopropane and salicylic acid on senescence regulation of gladiolus cut spikes. Scientia Horticulturae, v.179, p.146-152, 2014. DOI: https://doi.org/10.1016/j. scienta.2014.09.025

HE, Y.W.; LOH, C.S. Cerium and lanthanum promote floral initiation and reproductive growth of Arabidopsis thaliana. Plant Science, n.159, p.117-124, 2000. DOI: https://doi. org/10.1016/s0168-9452(00)00338-1

HEATH, R.L.; PARKER, L. Photoperoxidation in isolated chloroplast. I. Kinetics and stoichiometry of fatty acid peroxidation. Archives of Biochemistry and Biophysics, v.125, n.1, p.189-198, 1968. DOI: https://doi. org/10.1016/0003-9861(68)90654-1

HOUA, K.; BAO, D.; SHAN, C. Cerium improves the vase life of Lilium longiflorum cut flowers through ascorbateglutathione cycle and osmoregulation in the petals. Scientia Horticulturae, v.227, n.3, p.142-145, 2018. DOI: https:// doi.org/10.1016/j.scienta.2017.09.040

HUANG, L.F. The biological function of rare earth element. Acta Mathematica Sinica, v.15, p.693-695, 2002. 
ICHIMURA, K.; SHIMAMURA, M.; HISAMATSU, T. Role of ethylene in senescence of cut Eustoma flowers. Postharvest Biology and Technology, v.14, n.2, p.193-198, 1998. DOI: https://doi.org/10.1016/S09255214(98)00039-8

IN, B.C.; MOTOMURA, S.; INAMOTO, K.; DOI, M.; MORI, G. Multivariate analysis of relation between preharvest environmental factors, postharvest morphological and physiological factors and vase life of cut 'Asomi Red' roses. Japanese Society for Horticultural Science, v.76, n.1, p.66-72, 2007.

JADID SOLIMANDARABI, M.; HASHEMABADI, D.; ZAREDOST, F. The effect of potassium biofertilizer and chemical fertilizer on quantitative and qualitative traits of periwinkle (Catharanthus roseus cv. 'Acillata'). Journal of Ornamental Plants, v.7, n.4, p. 213-222, 2017.

JESSICA, T.D.; YUJI, A. Environmental geochemistry of cerium: Applications and toxicology of cerium oxide nanoparticles. International Journal of Environmental Research and Public Health, v.12, p.1253-1278, 2015. doi: https://doi.org/10.3390/ijerph120201253

KABARI, S.F.M; SOLIMANDARABI, M.J. Improving Alstroemeria vase life by plant extracts and 8-hydroxyquinoline sulfate. Journal of Ornamental Plants, v.9, n.1, p.1-11, 2019.

KADER, A.A. A perspective on postharvest horticulture (1978-2003). HortScience, v.38, n.5, p.1004-1008, 2003. DOI: https://doi.org/10.21273/HORTSCI.38.5.1004

KANG, R.Y.; YU, Z.F. Effects of chitosan and calcium chloride coating treatments on the enzyme activities of Yangshan peach during refrigerated storage. Changjiang Fruits, p.12-14, 2005.

KAZEMI, M.; ARAN, M.; ZAMANI, S. Extending the vase life of lisianthus (Eustoma grandiflorum mariachi. cv. Blue) with different preservatives. American Journal of Plant Physiology, v.6, n.3, p.167-175, 2011. DOI: https:// doi.org/10.3923/ajpp.2011.167.175

KAZEMI, M.; HADAVI, E.; HEKMATI, J. Role of salicylic acid in decreases of membrane senescence in cut carnation flowers. American Journal of Plant Physiology, v.6, n.2, p.106-112, 2011. DOI: https://doi.org/10.3923/ ajpp.2011.106.112.

KUMAR, N.; SRIVASTAVA, G.C.; DIXIT, K. Role of sucrose synthase and invertases during petal senescence in rose (Rosa hybrida L.). Journal of Horticultural Science and Biotechnology, v.83, p. 520-524, 2008. https:// doi.org /10.1080/ 14620316. 2008. 11512416
LAY-YEE, M.; STEAD, A.D.; REID, M.S. Flower senescence in daylily (Hemerocallis). Plant Physiology, v.86. p. 308-314, 1992. https://doi.org/10.1034/j.13993054.1992.860218.x

LIANG, C.; HUANG, X.; TAO, W.; ZHOU, Q. Effect of rare earths on plants under supplementary ultraviolet-B radiation: II. Effect of cerium on antioxidant defense system in rape seedlings under supplementary ultraviolet-B radiation. Journal of Rare Earths, v.24, n.3, p.364-368, 2006. DOI: https://doi.org/10.1016/S1002-0721(06)60125-7

LIU, J.; ZHANG, Z.; JOYCE, D.C.; HE, S.; CAO, J.; LV. P. Effect of postharvest nanosilver treatments on cut flowers. Acta Horticulturae, v.847, p.245-250, 2009. DOI: https:// doi.org/10.17660/ActaHortic.2009.847.31

LIU, R.; SHAN, C.; GAO, Y.; WANG, J.; XU, Z.; ZHANG, L.; MA, W.; TAN, R. Cerium improves the copper tolerance of turf grass Poa pratensis by affecting the regeneration and biosynthesis of ascorbate and glutathione in leaves. Brazilian Journal of Botany, v.39, p.779-785, 2016. DOI: https://doi.org/10.1007/s40415-015-0246-7

LU, X.;SUN, D.;LI, Y.; SHI, W.; SUN, G. Pre- and postharvest salicylic acid treatments alleviate internal browning and maintain quality of winter pineapple fruit. Scientia Horticulturae, v.130, p. 97-101, 2011. DOI: https://doi.org/10.1016/j.scienta.2011.06.017

MASHHADIAN, N.V; TEHRANIFAR, A.; BAYAT, H.; SELAHVARZI, Y. Salicylic and citric acid treatments improve the vase life of cut chrysanthemum flowers. Journal of Agricultural Science and Technology, v.14, n.4, p.879-887, 2012.

MANSOURI, H. Salicylic acid and sodium nitroprusside improve postharvest life of chrysanthemums. Scientia Horticulturae, v.145, p.29-33, 2012. DOI: https://doi. org/10.1016/j.scienta.2012.07.016

MAYER, A.M.; HAREL, E. Polyphenol oxidases in plants. Phytochemistry, v.18, p.193- 215, 1979. DOI: https://doi. org/10.1016/0031-9422(79)80057-6

MITTLER, R. Oxidative stress, antioxidants and stress tolerance. Trends in Plant Science, v.7, p. 405-410, 2002. DOI: https://doi.org/10.1016/S1360-1385(02)02312-9

MITTLER, R.; ZILINSKAS, B.A. Regulation of pea cytosolic ascorbate peroxidase and other antioxidant enzymes during the progression of drought stress and following recovery from drought. Plant Journal, v.5, p.397-405, 1994. DOI: https://doi.org/10.1111/j.1365313x.1994.00397.x. 
MORI, I.C.; PINONTOAN, R.; KAWANO, T.; MUTO, $\mathrm{S}$. Involvement of superoxide generation in salicylic acid induced stomatal closure in Vicia faba. Plant Cell Physiology, v.42, n.12, p.1383-1388, 2001. DOI: https:// doi.org/10.1093/pcp/pce176

NAKANO, Y.; ASADA, K. Hydrogen peroxide is scavenged by ascorbate specific peroxidase in spinach chloroplasts. Plant Cell Physiology, v.22, n.5, p.867-880, 1981. DOI: https://doi.org/10.1093/oxfordjournals.pcp. a076232

NELL, T.A. Effect of exogenous sucrose on carbohydrate levels, flower respiration longevity of poted miniature rose flowers during post production. Postharvest Biology and Technology, v.26, n.2, p.977-982, 2002. DOI: https://doi. org/10.1016/S0925-5214(02)00010-8

NICOLI, M.C.; ELIZABLE, B.E.; PIOTTI, A.; LERICI, C.R. Effect of sugar and maillard reaction products on polyphenol oxidase and peroxidase activity in food. Journal of Food Biochemistry, n.15, p.169-184, 1991. DOI: https://doi.org/10.1111/j.1745-4514.1991.tb00153.x

QINENG, L.; QING, Y.; HUAWEN, Z. Effects of cerium on accumulation of anthocyanins and expression of anthocyanin biosynthetic genes in potato cell tissue cultures. Journal of Rare Earths, v.4, p.479-484, 2006. DOI: https://doi.org/10.1016/S1002-0721(06)60147-6

RAHMANI, I.; AHMADI, N.; GHANATI, F., SADEGHI, M. Effects of salicylic acid applied pre- or post-transport on postharvest characteristics and antioxidant enzyme activity of gladiolus cut flower spikes. New Zealand Journal of Crop and Horticultural Science, v.43, p. 294-305, 2015. DOI: https://doi.org/10.1080/01140671.2015.1096799

ROHI, Z.; ASGHARI, M.R.; RASMI, Y.; ASLANI, Z. Effect of postharvest salicylic acid application on some quality attributes and antioxidant activity of kiwifruit (Actinidia Deliciosa cv. Hayward). Journal Of Horticulture Science (Agricultural Sciences And Technology), v.24, p.102-108, 2010.

SADEGHI, A.; NASIBI, F.; FARAHMAND, H.; HOSSENI, F. Effect of hydrogen peroxide treatment on improvement of the postharvest quality of cut Alstroemeria cut flowers. Iranian Journal of Horticultural Science, v.48, n.1, p.123-131, 2017. DOI: https://doi.org/10.22059/ ijhs.2017.117424.709

SAEEDI, R.; ETEMADI, N.; NIKBAKHT, A. Calcium chelated with amino acids improves quality and postharvest life of lisianthus (Eustoma grandiflorum cv. Cinderella Lime). HortScience, v.50, n.9, p.1394-1398, 2015. DOI: https://doi.org/10.21273/HORTSCI.50.9.1394
SHAN, C.; ZHAO, X. Lanthanum delays the senescence of Lilium longiflorum cut flowers by improving antioxidant defense system and water retaining capacity. Scientia Horticulturae, n.197, p.516-520, 2015. DOI: https:// doi. org $/ 10.1016 /$ j. scienta. 2015.10.012

SHARIFZADEH, K.; HASSANPOUR ASIL, M.; ROEIN, Z.; SHARIFZADEH, M. Effect of 8-hydroxyquinoline citrate, sucrose and peroxidase inhibitors on vase life of lisianthus (Eustoma grandiflorum L.) cut flowers. Journal of Horticultural Research, v.22, n.1, p.41-47, 2014. DOI: https://doi.org/10.2478/johr-2014-0005

SHYAM, R.; AERY, N.C. Effect of cerium on growth, dry matter production, biochemical constituents and enzymatic activities of cowpea plants [Vigna unguiculata (L.) Walp.]. Journal of Soil Science and Plant Nutrition, v.12, n.1, p.1-14, 2012. http://dx.doi.org/10.4067/S071895162012000100001

SILVA, J.A.T. The cut flower: Postharvest considerations. Journal of Biological Sciences, v.3, n.4, p.406-442, 2008. DOI: https://doi.org/10.3923/jbs.2003.406.442

SOOD, S.; VYAS, D.; NAGAR, P.K. Physiological and biochemical studies during flower development in two rose species. Scientia Horticulturae, v.108, p.390-396, 2006. DOI: https://doi.org/10.1016/j.scienta.2006.02.012

SONG, L.; LIU, H.; YOU, Y.; SUN, J.; YI, C.; LI, Y.; WU, J.S. Quality deterioration of cut carnation flowers involves in antioxidant systems and energy status. Scientia Horticulturae, v.170, p.45-52, 2014. DOI: https://doi. org/10.1016/j.scienta.2014.02.035

SRIVASTAVA, M.K.; DWIVEDI, U.N. Delayed ripening of banana fruit by salicylic acid. Plant Science, n.158, p.87-96, 2000. DOI: https://doi.org/10.1016/s01689452(00)00304-6

TIAN, S.; QIN, G.; LI, B.; WANG, Q.; MENG, X. Effects of salicylic acid on disease resistance and postharvest decay control of fruits. Stewart Postharvest Review, v.3, n.6, p.1-7, 2007. DOI: https://doi.org/10.2212/spr.2007.6.2

WANG, Q.; MU, J.; SHAN, C.; WANG, W.; FU, S. Effects of cerium on the antioxidant defence system in the petals and the contents of pigments in the calyces of Rosa chinensis Jacq. cut flower. Journal of Horticultural Science and Biotechnology, v.92, n.6, p.630-635, 2017. DOI: https://doi.org/10.1080/14620316.2017.1338924

WOLLASTON, V.B; EARL, S.; HARRISON, E.; MATHAS, E.; NAVABPOUR, S.; PAGE, T.; PINK, D. The molecular analysis of plant senescence a genomics approach. Plant Biotechnology Journal, v.1, n.1, p.3-22, 2003. DOI: https://doi.org/10.1046/j.1467-7652.2003.00004.x 
WU, M.; WANG, P.; SUN, L.; ZHANG, J.; YU, J.; WANG, Y.; CHEN, G.X. Alleviation of cadmium toxicity by cerium in rice seedlings is related to improved photosynthesis, elevated antioxidant enzymes and decreased oxidative stress. Plant Growth Regulation, n.74, p.251-260, 2014. DOI: https://doi.org/10.1007/s10725-014-9916-x

YIN, S.; ZE, Y.; LIU, C.; LI, N.; ZHOU, M.; DUAN, Y.; HONG, F. Cerium relieves the inhibition of nitrogen metabolism of spinach caused by magnesium deficiency. Biological Trace Element Research, v.132, p.247-258, 2009. DOI: https://doi.org/10.1007/s12011-009-8392-z
ZHENG, M.; GUO, Y. Cerium improves the vase life of Dianthus caryophyllus cut flower by regulating the ascorbate and glutathione metabolism. Scientia Horticulturae, v.240, p.492-495, 2018. DOI: https://doi. org/10.1016/j.scienta.2018.06.046 